\title{
Procedural Errors During Root Canal Preparation Using Rotary NiTi Instruments Detected by Periapical Radiography and Cone Beam Computed Tomography
}

\author{
Ana Helena Gonçalves de ALENCAR ${ }^{1,2}$ \\ Paul M. H. DUMMER ${ }^{2}$ \\ Henrique César Marçal OLIVEIRA ${ }^{1}$ \\ Jesus Djalma PÉCORA ${ }^{3}$ \\ Carlos ESTRELA ${ }^{1}$ \\ ${ }^{1}$ Dental School, Federal University of Goiás, Goiânia, GO, Brazil \\ ${ }^{2}$ Dental School, Cardiff University, Cardiff; UK \\ ${ }^{3}$ Ribeirão Preto Dental School, University of São Paulo, Ribeirão Preto, SP, Brazil
}

\begin{abstract}
This study detected procedural errors created by rotary nickel-titanium (NiTi) instruments during root canal preparation by two imaging methods. Forty extracted human maxillary and mandibular molars were divided randomly into two groups and treated by two endodontists $(n=10)$ and two undergraduate dental students $(n=10)$. The ProTaper Universal ${ }^{\text {TM }}$ Rotary System was used to shape the canals and then they were filled using AH Plus ${ }^{\mathrm{TM}}$ sealer and gutta-percha. Periapical radiographs (PR) and cone beam computed tomography $(\mathrm{CBCT})$ images were obtained and two examiners, who evaluated them to verify the occurrence of procedural errors (fractured instruments, perforations, and canal transportation). The Chi-square test at 0.05 level of significance was used for statistical analyses. There were no significant differences $(\mathrm{p}>0.05)$ between the imaging methods. In the analysis of procedural errors, there was no significant difference $(\mathrm{p}>0.05)$ between the groups of operators (endodontists $v s$. students) nor between tooth groups (maxillary molars $v s$. mandibular molars). In view of the low incidence of procedural errors during root canal preparation performed by students the introduction of rotary NiTi instruments has potential in undergraduate teaching. PR and CBCT permitted the detection of procedural errors, but the CBCT images offer more recourse for diagnosis.
\end{abstract}

Key Words: nickel-titanium, rotary instruments, root canal preparation, dental education, cone beam computed tomography.

\section{INTRODUCTION}

Endodontic teaching requires scientific knowledge and appropriate methodological strategies to optimize the use of materials and techniques. Several challenges are present during undergraduate teaching, in particular, the recent conceptual changes in terms of the shaping of curved root canals.

It seems opportune to emphasize that shaping root canals is an essential phase on root canal treatment. An important innovation that has a major impact on this procedure has been the introduction of rotary NiTi instruments $(1,2)$. Rotary nickel-titanium (NiTi) instruments have been found to maintain working length
(WL), allow root canal preparation to be more centered and better tapered, create fewer procedural errors when compared to stainless steel instruments, in addition to being faster (1-5).

A number of new rotary NiTi instruments with particular characteristics have been introduced over the last years (3-7). The promising potential of NiTi instruments in shaping curved root canals are thus available to undergraduate dental students during their training at the dental schools (6-10). The viability of teaching new techniques and using new materials to improve the quality of root canal treatment in the undergraduate program is essential when considering contemporary educational perspectives (8-10). However, 
several factors might influence negatively the application of these techniques in undergraduate teaching such as risk of instrument fracture, root perforation, deviation of the root canal, cost, etc. In fact, it has been a concern, and several studies have already evaluated the performance of NiTi systems in undergraduate teaching (7-12).

Cone beam computed tomography (CBCT) has been used in endodontic therapy for study of root canal anatomy, evaluation of root canal preparation and filling, retreatment, and experimental endodontics. CBCT images provide a significantly faster image acquisition and reconstruction scheme, offering high-resolution images that allow more accurate identification of apical periodontitis than periapical radiographs (PR) (13-16).

In view of the importance of introducing undergraduate dental students to NiTi rotary instruments, this study aimed at detecting procedural errors occurred during root canal preparation using rotary $\mathrm{NiTi}$ instruments employing different imaging methods.

\section{MATERIAL AND METHODS}

This study was approved by the Research Ethics Committee of the Federal University of Goiás, Brazil, (protocol number 074-2009), and written informed consent was obtained from all patients.

\section{Tooth Preparation}

Forty extracted human maxillary and mandibular molars, obtained from the Dental Emergency Service of the Dental School of the Federal University of Goiás, Brazil, were selected.

Preoperative PR were taken of each tooth to verify the absence of a calcified root canal, internal or external resorption, and to confirm the presence of fully formed root apices. In each tooth, three root canals were evaluated (maxillary molars: palatal canal, mesiobuccal canal, distobuccal canal; mandibular molars: distal canal, mesiobuccal canal, mesiolingual canal). Curvature of the root was determined according to Estrela et al. (17). All teeth were less than $22 \mathrm{~mm}$ in length and had a moderate curvature, with radius $\mathrm{r}>4 \mathrm{~mm}$ and $\leq 8$ $\mathrm{mm}$. The extracted teeth were immersed in $5 \%$ sodium hypochlorite (Fitofarma, Lt. 20442, Goiânia, GO, Brazil) for $30 \mathrm{~min}$ to remove organic tissue and then stored in $0.2 \%$ thymol solution.

Periapical radiographs were exposed using a Spectro X70 electronic x-ray unit (Dabi Atlante, Ribeirão
Preto, SP, Brazil) with a $0.8 \mathrm{~mm} \times 0.8 \mathrm{~mm}$ tube focal spot, Kodak Insight film-E (Eastman Kodak Co, Rochester, NY, USA) and a parallel radiographic technique. The films were processed in an automatic processor. To standardize radiographs, a special platform was used for all teeth.

\section{Root Canal Preparation}

The teeth were assigned randomly to two experimental groups: Group 1A: maxillary molars, $\mathrm{n}=10$; endodontists; Group 1B: mandibular molars, $\mathrm{n}=10$; endodontists; Group 2A: maxillary molars, $\mathrm{n}=10$; undergraduate dental students; Group 2B: mandibular molars, $n=10$; undergraduate dental students.

Standard access cavities were prepared with round diamond burs (\#1013,\#1014; KG Sorensen, Barueri, SP, Brazil) and Endo Z burs (Dentsply Maillefer, Ballaigues, Switzerland) in a high speed handpiece with air-water spray cooling. The WL was determined using sizes 10 and $15 \mathrm{~K}$-Flexofiles (Dentsply Maillefer) introduced into all root canals until visible at the apical foramen. The WL was set $1 \mathrm{~mm}$ short of this length.

Two endodontists with more than 5 years of experience, registered at the Brazilian Dentistry Association (Goiânia, GO, Brazil), and two last-year undergraduate dental students of Dental School of the Federal University of Goiás, Brazil, prepared the root canals. The operators had an 8-h theoretical course on rotary NiTi instrumentation and the ProTaper ${ }^{\mathrm{TM}}$ Universal Rotary System (Dentsply Maillefer).

The ProTaper Universal ${ }^{\mathrm{TM}}$ Rotary System (Dentsply Maillefer) was used both by the endodontists and the dental students. The root canals were shaped at a rotational speed of $300 \mathrm{rpm}$ (Endo-Mate TC electric motor, NSK, Nakanishi Inc., Tokyo, Japan) and 2.9 Ncm torque as follows: 1) SX instrument was used to prepare the cervical third; 2) S1 and S2 instruments to WL; and 3) F1, F2, and F3 instruments to WL. During root canal preparation, the root canals were irrigated with $3 \mathrm{~mL}$ of a recently prepared $1 \%$ sodium hypochlorite (Fitofarma), using a syringe with a 30-gauge needle (Injecta, Diadema, SP, Brazil), at each change of instrument. Root canals were dried and filled with $17 \%$ EDTA, pH 7.2, (Biodinâmica, Ibiporã, PR, Brazil) for $3 \mathrm{~min}$ to remove the smear layer, followed by irrigation with $3 \mathrm{~mL}$ of $1 \%$ sodium hypochlorite. The mean time required for root canal preparation for both groups of operators was recorded. 


\section{Root Canal Filling}

After completion of the root canal preparation, all canals were filled by an endodontist who did not take part in the canal preparation phase, with lateral condensation of gutta-percha cones and $\mathrm{AH}$ Plus $^{\mathrm{TM}}$ sealer (Dentsply Maillefer) mixed according to the manufacturer's instructions.

New periapical radiographs were taken after filling the root canals using the methods described previously.

CBCT images were then obtained with an I-CAT Cone Beam 3D imaging system (Imaging Sciences International, Hatfield, PA, USA), $0.20 \mathrm{~mm} \times 0.20$ $\mathrm{mm} \times 0.20 \mathrm{~mm}$ voxel size, 14 bits. The images were examined using Xoran version 3.1.62 software (Xoran Technologies, Ann Arbor, MI, USA) in a PC workstation running Microsoft Windows XP professional SP-2 (Microsoft Corp, Redmond, WA, USA).

Two calibrated examiners evaluated all images to determine the presence of fractured instruments, root perforations (coronal, middle, or apical third), and filling material out of the pathway of the root canal in the apical third (canal transportation). Fracture of instruments was also recorded during the root canal preparation. When a consensus was not reached between the two examiners after their interpretation of the procedural errors based on the images, a third calibrated examiner made a final decision. The examiners analyzed the results with an interval of $2 \mathrm{~h}$ between groups and without knowledge of the operator group.

The Chi-square test at the 0.05 level of significance was used to determine differences in procedural errors between the two groups of operators, differences in error detection using PR and CBCT, and differences in procedural errors between maxillary and mandibular teeth.

\section{RESULTS}

The distribution and frequency of procedural errors by operator group and imaging methods are described in Tables 1 and 2. There were no significant differences $(p>0.05)$ comparing the imaging methods. In the analysis of procedural errors (fractured instruments, perforations and canal transportation), there was no difference between the groups of operators or between the tooth groups $(p>0.05)$. The mean time required for root canal preparation varied among operators, with a mean time of $10 \mathrm{~min}$ for specialists and $30 \mathrm{~min}$ for dental students. Figure 1 shows cases of canal transportation, fractured instruments, and root perforations observed by periapical radiographs and $\mathrm{CBCT}$ images.

\section{DISCUSSION}

During root canal preparation several critical factors must be taken into account, such as the instruments and the technique used, as well as the operator's and experience. The advent of new strategies for root canal preparation and evaluation of the quality of the outcome has modified the perception of instrumentation and the operator's skills (17-20).

Several methodologies have been used to evaluate the quality of procedures in the treatment of curved root canal, such as tooth decalcification, taking impression of canals, simulated canals, and radiographs (4-11,18-20). However, the destruction of the specimens may impede the simultaneous investigation of different parameters of root canal preparation, and place limitations on these methods $(19,20)$.

Different advanced imaging techniques, such as microcomputed tomography $(\mu \mathrm{CT})$, cone beam volumetric imaging, and $\mathrm{CBCT}$ have been used to analyze canal preparation shape in three dimensions, particularly for their accuracy in detecting procedural errors $(14,19,20)$.

In the present study, both imaging methods - PR and $\mathrm{CBCT}$ - permitted the identification of procedural errors images after root canal preparation. Although the differences between these two methods were not significant, CBCT images permitted observations of the root canal in three-dimensional planes (axial, transverse, and tangent planes). The axial slice from CBCT images constituted an important tool to identify root perforations and canal transportation.

The risk of instrument fracture represents a dilemma in rotary root canal preparation. Hand instruments tend to deform before fracture occurs, which could be avoided by constantly monitoring the spirals. The only real warning of rotary instrument fracture has been the sudden sound that occurs (13). Various factors have been discussed in the literature to explain the fracture of NiTi instruments, such as design characteristics, technique, knowledge, experience, and training of operators $(5,13)$.

An analysis of procedural errors revealed no difference in the number of fractured instruments 
Table 1. Distribution of procedural errors by operator using periapical radiograph (PR).

\begin{tabular}{|c|c|c|c|c|c|c|c|c|c|c|c|c|}
\hline \multirow{3}{*}{ Group } & \multirow{3}{*}{$\mathrm{n}$} & \multirow{3}{*}{ Canal } & \multirow{2}{*}{\multicolumn{2}{|c|}{$\begin{array}{l}\text { Instrument } \\
\text { fracture }\end{array}$}} & \multicolumn{6}{|c|}{ Perforation } & \multirow{2}{*}{\multicolumn{2}{|c|}{$\begin{array}{c}\text { Canal } \\
\text { transportation }\end{array}$}} \\
\hline & & & & & \multicolumn{2}{|c|}{ Coronal third } & \multicolumn{2}{|c|}{ Middle third } & \multicolumn{2}{|c|}{ Apical third } & & \\
\hline & & & Yes & No & Yes & No & Yes & No & Yes & No & Yes & No \\
\hline \multirow{3}{*}{$\begin{array}{l}\text { Endodontists } \\
\text { Maxillary } \\
\text { molars }\end{array}$} & 10 & $\mathrm{PC}$ & 1 & 9 & 0 & 10 & 0 & 10 & 0 & 10 & 0 & 10 \\
\hline & 10 & $\mathrm{MBC}$ & 1 & 9 & 0 & 10 & 0 & 10 & 0 & 10 & 0 & 10 \\
\hline & 10 & $\mathrm{DBC}$ & 0 & 10 & 0 & 10 & 0 & 10 & 0 & 10 & 0 & 10 \\
\hline \multirow{3}{*}{$\begin{array}{l}\text { Endodontists } \\
\text { Mandibular } \\
\text { molars }\end{array}$} & 10 & $\mathrm{DC}$ & 0 & 10 & 0 & 10 & 0 & 10 & 0 & 10 & 0 & 10 \\
\hline & 10 & $\mathrm{MBC}$ & 0 & 10 & 0 & 10 & 0 & 10 & 0 & 10 & 1 & 9 \\
\hline & 10 & MLC & 0 & 10 & 0 & 10 & 0 & 10 & 0 & 10 & 0 & 10 \\
\hline \multirow{3}{*}{$\begin{array}{l}\text { Students } \\
\text { Maxillary } \\
\text { molars }\end{array}$} & 10 & $\mathrm{PC}$ & 0 & 10 & 0 & 10 & 0 & 10 & 0 & 10 & 0 & 10 \\
\hline & 10 & $\mathrm{MBC}$ & 0 & 10 & 0 & 10 & 0 & 10 & 0 & 10 & 3 & 7 \\
\hline & 10 & $\mathrm{DBC}$ & 0 & 10 & 0 & 10 & 0 & 10 & 0 & 10 & 0 & 10 \\
\hline \multirow{3}{*}{$\begin{array}{l}\text { Students } \\
\text { Mandibular } \\
\text { molars }\end{array}$} & 10 & DC & 0 & 10 & 1 & 9 & 0 & 10 & 0 & 10 & 0 & 10 \\
\hline & 10 & $\mathrm{MBC}$ & 2 & 8 & 2 & 8 & 1 & 9 & 1 & 9 & 1 & 9 \\
\hline & 10 & MLC & 0 & 10 & 0 & 10 & 0 & 10 & 0 & 10 & 0 & 10 \\
\hline
\end{tabular}

PC: palatal canal; MBC: mesiobuccal canal; DBC: distobuccal canal; DC: distal canal; MLC: mesiolingual canal.

There was no difference in the imaging methods, procedural errors between operators or between tooth groups ( $\mathrm{p}>0.05)$.

Table 2. Distribution of procedural errors by operator using cone beam computed tomography (CBCT) images.

\begin{tabular}{|c|c|c|c|c|c|c|c|c|c|c|c|c|}
\hline \multirow{3}{*}{ Group } & \multirow{3}{*}{$\mathrm{n}$} & \multirow{3}{*}{ Canal } & \multirow{2}{*}{\multicolumn{2}{|c|}{$\begin{array}{l}\text { Instrument } \\
\text { fracture }\end{array}$}} & \multicolumn{6}{|c|}{ Perforation } & \multirow{2}{*}{\multicolumn{2}{|c|}{$\begin{array}{c}\text { Canal } \\
\text { transportation }\end{array}$}} \\
\hline & & & & & \multicolumn{2}{|c|}{ Coronal third } & \multicolumn{2}{|c|}{ Middle third } & \multicolumn{2}{|c|}{ Apical third } & & \\
\hline & & & Yes & No & Yes & No & Yes & No & Yes & No & Yes & No \\
\hline \multirow{3}{*}{$\begin{array}{l}\text { Endodontists } \\
\text { Maxillary } \\
\text { molars }\end{array}$} & 10 & $\mathrm{PC}$ & 1 & 9 & 0 & 10 & 0 & 10 & 0 & 10 & 0 & 10 \\
\hline & 10 & $\mathrm{MBC}$ & 1 & 9 & 0 & 10 & 0 & 10 & 0 & 10 & 0 & 10 \\
\hline & 10 & $\mathrm{DBC}$ & 0 & 10 & 1 & 9 & 0 & 10 & 0 & 10 & 0 & 10 \\
\hline \multirow{3}{*}{$\begin{array}{l}\text { Endodontists } \\
\text { Mandibular } \\
\text { molars }\end{array}$} & 10 & $\mathrm{DC}$ & 0 & 10 & 0 & 10 & 0 & 10 & 0 & 10 & 0 & 10 \\
\hline & 10 & $\mathrm{MBC}$ & 0 & 10 & 0 & 10 & 0 & 10 & 0 & 10 & 1 & 9 \\
\hline & 10 & MLC & 0 & 10 & 0 & 10 & 0 & 10 & 0 & 10 & 1 & 9 \\
\hline \multirow{3}{*}{$\begin{array}{l}\text { Students } \\
\text { Maxillary } \\
\text { molars }\end{array}$} & 10 & $\mathrm{PC}$ & 0 & 10 & 0 & 10 & 0 & 10 & 0 & 10 & 0 & 10 \\
\hline & 10 & $\mathrm{MBC}$ & 0 & 10 & 0 & 10 & 0 & 10 & 0 & 10 & 3 & 7 \\
\hline & 10 & $\mathrm{DBC}$ & 0 & 10 & 0 & 10 & 0 & 10 & 0 & 10 & 0 & 10 \\
\hline \multirow{3}{*}{$\begin{array}{l}\text { Students } \\
\text { Mandibular } \\
\text { molars }\end{array}$} & 10 & DC & 0 & 10 & 1 & 9 & 0 & 10 & 0 & 10 & 0 & 10 \\
\hline & 10 & $\mathrm{MBC}$ & 2 & 8 & 2 & 8 & 1 & 9 & 1 & 9 & 1 & 9 \\
\hline & 10 & MLC & 0 & 10 & 0 & 10 & 0 & 10 & 0 & 10 & 3 & 7 \\
\hline
\end{tabular}

PC: palatal canal; MBC: mesiobuccal canal; DBC: distobuccal canal; DC: distal canal; MLC: mesiolingual canal. There was no significant difference in the imaging methods, procedural errors between operators or between tooth groups ( $\mathrm{p}>0.05)$. 
between different levels of operator experience $(2 / 60)$ nor between tooth groups $(2 / 20)$. Baumann and Roth (13) reported no differences in rotary instrument breakage rates during root canal preparation performed by undergraduates $(8 / 170)$ and professionals $(8 / 170)$. Sonntag et al. (4) observed that inexperienced operators achieved better canal preparation using rotary NiTi instruments compared to hand stainless instruments, despite creating more fractures $(14 / 105)$.

The results of the present study revealed that perforations and canal transportations were more frequent among undergraduates than among specialists, though without significant different. This reflects the finding Baumann and Roth (13) who compared inexperienced dental students with experienced dentists for their ability to use rotary NiTi instruments. Both
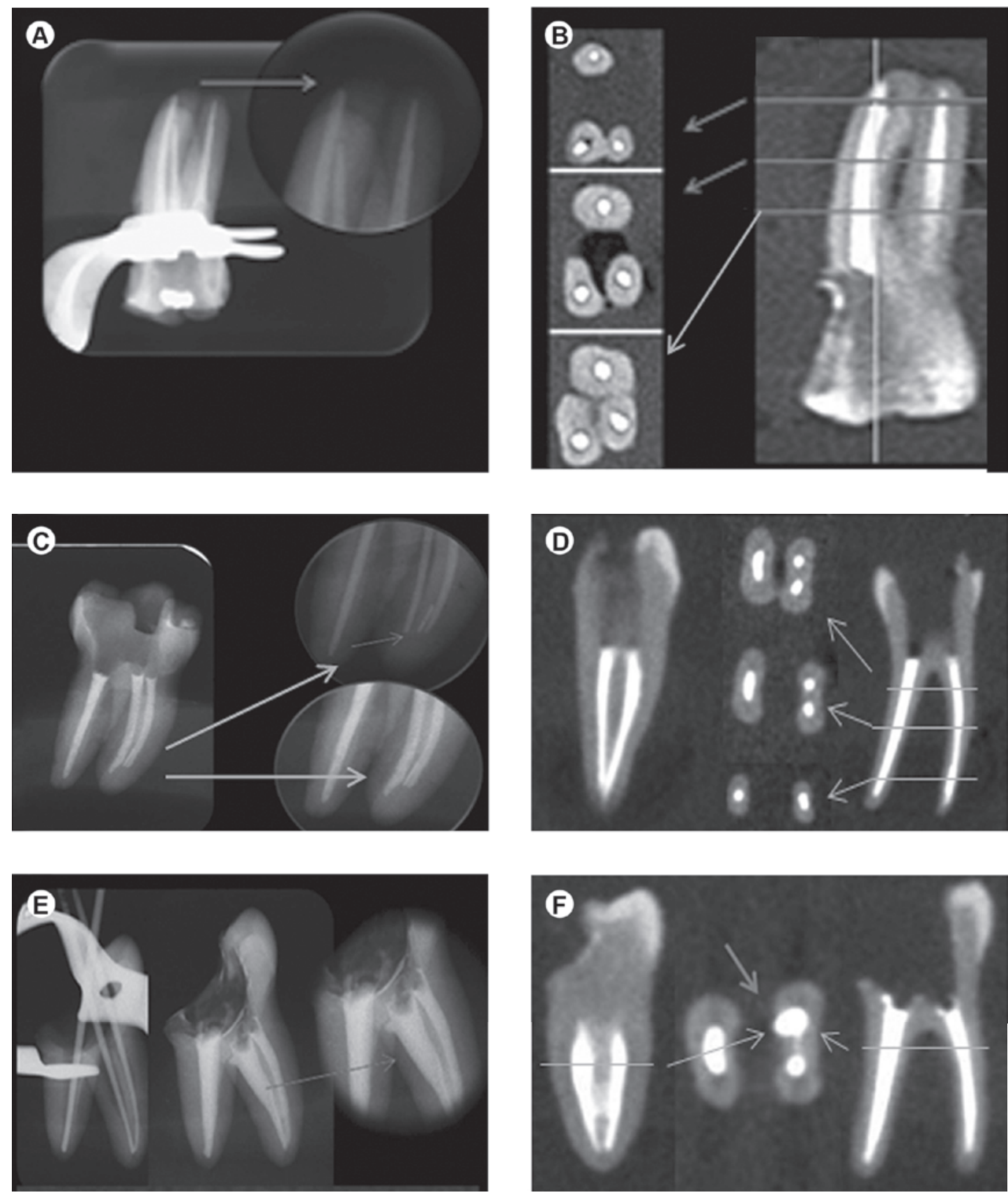

Figure 1. Canal transportation, fractured instruments and root perforations observed in periapical radiographs (A, C, E) and CBCT scans $(\mathrm{B}, \mathrm{D}, \mathrm{F})$. 
groups successfully used rotary NiTi instruments and achieved good root canal geometry.

Gekelman et al. (10) evaluated canal preparations achieved ex vivo by undergraduate dental students using $\mu \mathrm{CT}$. The results revealed that the qualitative and quantitative data for canal transportation were similar to earlier studies with experienced operators. Studies performed by Tu et al. (20) and Gekelman et al. (10) determined that receiving structured training sessions, and following the preparation sequence carefully, allowed undergraduate students to shape canals successfully employing rotary instruments.

In the present study, ProTaper Universal ${ }^{\mathrm{TM}}$ NiTi rotary instruments were used, and the canals were enlarged to F3 at WL, corresponding to a size 30, 0.09 taper master file. The specimens were selected, on the basis of having a moderate curvature with a radius $r>4$ $\mathrm{mm}$ and $\leq 8 \mathrm{~mm}$. The frequency of procedural errors was low, with no impact created by the level of experience and knowledge of the operators.

In the present study, the time required for root canal preparation varied according to the operator, with a mean value of $10 \mathrm{~min}$ for specialists and 30 min for students. Sonntag et al. (4) observed that the mean time taken for preparation of simulated canals by inexperienced operators was $12 \mathrm{~min}$ with rotary instruments (FlexMaster NiTi). Also, Mesgouez et al. (3) determined the influence of operator experience on canal preparation time when using Profile rotary NiTi instruments in simulated curved canals. The mean preparation time was 2 min $42 \mathrm{~s}$ per canal. The time required for canal preparation was inversely proportional to operator experience.

Dental schools worldwide have assessed the use of rotary NiTi instruments for curved root canal preparation $(4,6,8,-12,15,18)$. French dental schools have advocated the use of rotary NiTi techniques and have incorporated lectures and laboratory courses related to these systems to their undergraduate dental curriculum (9).

In light of the low incidence of procedural errors during root canal preparation made by students, the introduction of rotary NiTi instruments in undergraduate teaching seems promising. Further studies are essential to evaluate the performance of rotary NiTi instruments when enlargement of curved root canals beyond size 30 is necessary. This would better characterize the teaching parameters and their use in clinical undergraduate courses.
Although both imaging methods used in this study permitted the detection of procedural errors, CBCT exams offer more resources for an accurate diagnosis.

\section{ACKNOWLEDGEMENTS}

This study was supported by grants from CNPq (grant $302875 / 2008-5$ to the author C.E.) and CAPES (grant BEX 0947/09-1 to the author A.H.G.A).

\section{RESUMO}

O objetivo deste estudo foi determinar erros de procedimentos ocorridos durante o preparo de canais radiculares após o uso de instrumentos de níquel-titânio (NiTi) acionados a motor, avaliados por dois métodos de exame por imagens. Quarenta molares humanos extraídos, superiores e inferiores, foram aleatoriamente divididos em dois grupos e tratados por dois especialistas em Endodontia $(n=10)$ e dois estudantes de Odontologia $(n=10)$. O sistema rotatório ProTaper Universal ${ }^{\mathrm{TM}}$ foi usado para preparar os canais radiculares e, a seguir estes foram obturados com cimento AH Plus ${ }^{\mathrm{TM}}$ e guta percha. Radiografias periapicais (RP) e tomografia computadorizada de feixe cônico (TCFC) foram obtidas e avaliadas por dois examinadores para verificar a ocorrência de erros de procedimentos (instrumentos fraturados, perfurações e transporte apical). O teste do qui-quadrado com nível de significância de 0,05 foi usado para análise estatística. Frente a comparação dos métodos de exames por imagens não houve diferenças significantes $(\mathrm{p}>0,05)$. Na análise de erros de procedimentos (fraturas de instrumentos, perfurações e transportes apicais) não houve diferenças estatisticamente significantes nos níveis de operadores e nem entre grupos de dentes. Em vista da baixa incidência de erros de procedimentos durante o preparo de canais radiculares realizados por estudantes, a introdução de instrumentos de NiTi apresenta potencial no ensino da graduação. RP e TCFC permitiram detectar erros de procedimentos durante o preparo de canais radiculares, porém, a TCFC oferece maiores recursos para o diagnóstico.

\section{REFERENCES}

1. Walia H, Brantley WA, Gerstein H. An initial investigation of the bending and torsional properties of nitinol root canal files. J Endod 1988; 14:346-351.

2. Esposito PT, Cunningham CJ. A comparison of canal preparation with nickel-titanium and stainless steel instruments. J Endod 1995;21:173-176.

3. Mesgouez C, Rilliard F, Matossian L, Nassiri K, Mandel E. Influence of operator experience on canal preparation time when using the rotary Ni-Ti ProFile system in simulated curved canals. Int Endod J 2003;36:161-165.

4. Sonntag D, Delschen S, Stachniss V. Root-canal shaping with manual and rotary Ni-Ti files performed by students. Int Endod $\mathrm{J}$ 2003;36:715-723.

5. Hülsmann M, Peters OA, Dummer PMH. Mechanical preparation of root canals: shaping goals, techniques and means. Endod Topics 2005; 10:30-76.

6. Pettiette MT, Delano EO, Trope M. Evaluation of success rate of endodontic treatment performed by students with stainless-steel 
K-files and nickel-titanium hand files. J Endod 2001;27:124-127.

7. Yared GM, Bou Dagher FE, Machtou P. Influence of rotational speed, torque and operator's proficiency on Profile failures. Int Endod J 2001;34:47-53.

8. Hänni S, Schönenberger K, Peters OA, Barbakow F. Teaching an engine-driven preparation technique to undergraduates: initial observations. Int Endod J 2003;36:476-482.

9. Arbab-Chirani R, Vulcain JM. Undergraduate teaching and clinical use of rotary nickel-titanium endodontic instruments: a survey of French dental schools. Int Endod J 2004;37:320-324.

10. Gekelman D, Ramamurthy R, Mirfarsi S, Paqué F, Peters OA. Rotary nickel-titanium GT and ProTaper files for root canal shaping by novice operators: a radiographic and micro-computed tomography evaluation. J Endod 2009;35:1584-1588.

11. Himel VT, Ahmed KM, Wood DM, Alhadainy HA. An evaluation of nitinol and stainless steel files used by dental students during a laboratory proficiency exam. Oral Surg Oral Med Oral Pathol Oral Radiol Endod 1995;79:232-237.

12. Peru M, Peru C, Mannocci F, Sherriff M, Buchanan LS, PittFord TR. Hand and nickel-titanium root canal instrumentation performed by dental students: a micro-computed tomographic study. Eur J Dent Educ 2006;10:52-59.

13. Baumann MA, Roth A. Effect of experience on quality of canal preparation with rotary nickel-titanium files. Oral Surg Oral Med Oral Pathol Oral Radiol Endod 1999;88:714-748.

14. Cotton TP, Geisler TM, Holden DT, Schwartz SA, Schindler WG.
Endodontic applications of cone-beam volumetric tomography. J Endod 2007;33:1121-1132.

15. Estrela C, Bueno MR, Leles CR, Azevedo B, Azevedo JR. Accuracy of cone beam computed tomography and panoramic and periapical radiography for detection of apical periodontitis. J Endod 2008;34: 273-279.

16. Estrela C, Bueno MR, Azevedo BC, Azevedo JR, Pécora JD. A new periapical index based on cone beam computed tomography. J Endod 2008;34:1325-1331.

17. Estrela C, Bueno MR, Sousa-Neto MD, Pécora JD. Method for determination of root curvature radius using cone-beam computed tomography images. Braz Dent J 2008;19:114-118.

18. Pécora JD, Capelli A, Guerisoli DMZ, Spanó JCE, Estrela C. Influence of cervical preflaring on apical file size determination. Int Endod J 2005;38:430-435.

19. Peters OA, Laib A, Rüegsegger P, Barbakow F. Three-dimensional analysis of root canal geometry by high-resolution computed tomography. J Dent Res 2000;79;1405-1409.

20. Tu MG, Chen SY, Huang HL, Tsai CC. Endodontic shaping performance using nickel-titanium hand and motor ProTaper systems by novice dental students. J Formos Med Ass 2008;107:381-388.

Accepted November 4, 2010 